\title{
Citric Acid Produced From Citrus Medica and its Peel as a Substrate and Effect of Alcohols at Different Concentrations
}

\author{
M. Sashi Prabha ${ }^{1}$, G. Subba Rangaiah ${ }^{2}$ \\ ${ }^{1}$ Department of Microbiology, Dr. Lankapalli Bullayya P.G. College and Research center, Visakhapatnam, Andhra Pradesh, India \\ ${ }^{2}$ Department of Microbiology, Andhra University, Visakhapatnam, Andhra Pradesh, India
}

\begin{abstract}
Citric acid i.e. 2-hydroxy propane,2,3-tricarboxylic acid ( СН2СООН.СОН.СООН.СН2СООН) is ubiquitous in nature. Citric acid is one of the most important bulk produced organic acids. In the present study more focus is on the economical grounds of citric acid production for which, different Citrus medica and its peels were selected as a substrates for the production, which can be proved economical. In order to fulfill the same Aspergillus niger MTCC 281 culture was used as a source of organisms, Citron (Citrus medica) and its peels which are dumped indiscriminately after extracting the edible portion and this uncontrolled activity leads to environmental pollution with the resultant health hazard to the populace. So, these municipal wastes were considered for the citric acid fermentation. The rate of production of citric acid using peel was compared with the production rate using the fruits (Citrus medica), which are in turn considered as a rich carbohydrate source. The whole productions i.e. fruit yield and fruit peel yield were compared with citric acid yield from Sucrose as a source of substrate. In the second part of the work test for effect of alcohols on the rate of production was studied to identify whether the respective alcohol is acting as a stimulant or as an inhibitor on the production rate. Three different alcohols were used (methanol, ethanol and Butanol) at different concentrations.
\end{abstract}

Keywords: Citric acid, Citrus medica, stimulants, substrate, Alcohols.

\section{Introduction}

Citric acid is a 6-Carbon containing tricarboxylic acid which was first isolated from lemon juice and was crystallized by Scheele in 1784. Citric acid i.e. 2-hydroxy propane,2,3tricarboxylic acid ( $\mathrm{CH} 2 \mathrm{COOH} . \mathrm{COH} . \mathrm{COOH} . \mathrm{CH} 2 \mathrm{COOH})$ is ubiquitous in nature and exists as an intermediate in the tricarboxylic acid cycle [1]. Citric acid obtained through the microbial fermentation is considered synthetic while that of present in fruits is referred to as natural [2][3]. Citric acid is one of the most important bulk-produced organic acids[4], having wide range of applications. The food and pharmaceutical industries utilize citric acid extensively because of its high solubility, pleasant sour taste. Very low toxicity and ready assimilability. Citric acid also find applications in some cosmetic preparations, in metal and chemical cleaning, electro pickling and copper plating, secondary oil recovery and other industries [5]. There are many other uses of citric acids which placed greater stress on increasing the citric acid production and search for more efficient processes.

The main aim of the study is to study on the citric acid production on the economical grounds using fruit waste as a substrate which are considered as a municipal waste. The specific fruit that was selected is Citrus medica (Citron) and its peel. Aspergillus niger (MTCC281) is the organism of choice that was selected for the production of citric acid.

In the second part of the study,effect of alcohols on the rate of production was studied.Three different alcohols were used (Methanol, Ethanol and Butanol), at different concentrations. Use of alchols is to identify wherether they are acting as a stimulant or as a inhibitor on the rate of production.Over all the main purpose of the present work is to get maximum amount of citric acid even from fruit waste which is considered as municipal waste.

\section{Materials and Methods}

\subsection{Materials}

- Organism used : Aspergillus niger MTCC281. The growth medium for the organism is Czapek Yeast Extract Agar medium (CYA), received from Microbial Type Culture Collection and Gene Bank.

- Instruments : $\mathrm{pH}$ meter, Autoclave, Orbital shaking Incubator, Colorimeter, Water bath, Electronic weighing balance.

- Substrates : Citrus medica (Citron) and its peel

\subsection{Methods}

The initial sugar concentration in fruit and its peel has been found to determine the amount of citric acid. Normally strains of A.niger need a fairly higher initial sugar concentration in the medium at a range of $15-18 \%$, w/v [6]. The higher sugar concentrations than the requirement lead to greater amounts of residual sugars making the process uneconomical [7]. In order to know the initial sugar concentration in the substrate Anthron's method was used.

The Anthrone method [8][9] This method is both quicker and more accurate and suites well for the determination of carbohydrates.

\subsection{Anthrone Reagent}

Anthrone reagent is prepared by dissolving $2 \mathrm{gm}$. Anthrone in $1 \mathrm{~L}$ of $95 \%$ sulphuric acid. This reagent has to be prepared fresh daily and was between 4 to 8 hours old. The 


\section{International Journal of Science and Research (IJSR) \\ ISSN (Online): 2319-7064 \\ Index Copernicus Value (2013): 6.14 | Impact Factor (2014): 5.611}

amounts of carbohydrate present in the substrate was determined i.e. the amount of carbohydrates present in the Citron and its peel was estimated using anthrone method. For this purpose, the fruits and its peel was collected and were then macerated or sliced separately, together with the expressed juice dried in a hot air oven at less than $60{ }^{0} \mathrm{C}$. They were then pulverized and stored in dark bottles. This enables to obtain a homogenous sample and to analyze aliquots repeatedly [10][11]. Aliquots of $1 / 2$ to $2 \mathrm{gm}$. Pulverized material were used for analysis[12] and followed the Morris anthrone method. The amount of carbohydrate in the test sample was estimated from a standard curve.

\section{Citric acid Production}

\section{Shake Flask Studies}

The Aspergillus niger cultures were used for citric acid production in $250 \mathrm{ml}$ Erlenmeyer flasks.

\section{Preparation of Conidial Inoculum}

Conidial inoculums were used in the present study. The spores from 4-6 days old slant cultures of PDA medium were used for the inoculation.

\section{Preparation of Vegetative Inoculums}

One hundred milliliters of the fermentation medium was added into a $1.0 \mathrm{~L}$ conical flask. The flask was cotton plugged sterilized at $15.0 \mathrm{lbs} / \mathrm{in}^{2}$ pressure $\left(121{ }^{0} \mathrm{C}\right)$ for 15 minutes. One milliliter of the A.niger conidial suspension $\left(1.2 \times 10^{6}\right.$ culture per $\left.\mathrm{ml}\right)$ was used for inoculation. The flask was incubated at $30{ }^{\circ} \mathrm{C}$ in a rotary shaking incubator at 200 rpm for 24 hour.

\section{Fermentation Technique}

The citric acid fermentation was carried out in a conical flask. $\mathrm{T}$ he fermentation medium was sterilized in a autoclave at $15.0 \mathrm{lbs} / \mathrm{in}^{2}$ pressure $\left(121^{\circ} \mathrm{C}\right)$ for 20 minutes. After cooling to about $30{ }^{\circ} \mathrm{C}$ or below, vegetative inoculums were transferred into the sterile fermentation medium at a level of $4.0 \%(\mathrm{v} / \mathrm{v})$. The incubation temperature was kept at $30{ }^{0} \mathrm{C}$ throughout the fermentation period of 144 hours. The shaking speed of the orbital shaker was adjusted to $160 \mathrm{rpm}$. The $\mathrm{pH}$ of fermentation medium was adjusted to 3.5 by $0.1 \mathrm{~N}$ $\mathrm{NaoH} / \mathrm{HCl}$ before autoclaving.

After the incubation period the ingredients of the flasks were filtered and the filtrate was used for the estimation of citric acid produced and residual sugar content. The dry cell mass was also calculated.

\section{Recovery}

Partial citric acid recovery was accomplished by the precipitation method [13]. After fermentation was completed fermentation broth was filtered completely. The filtrate was boiled with equivalent amount of lime and tri-calcium citrate, this involves precipitation method. The calcium citrate was filtered off and then treated with sulphuric acid $(60-70 \%, v / v)$ to obtain citric acid and precipitate of calcium sulphate.

\section{Effect of different alcohols at Various Concentrations}

The effect of different alcohols such as Methanol, Ethanol and Butanol at varying concentrations on citric acid fermentation by the strain Aspergillus niger MTCC281, using Citron and its peels as a carbohydrate substrate in shake flasks, was carried out. The concentration of alcohols varied from 0.5 to $2.5 \%,(\mathrm{v} / \mathrm{v})$. The same was performed with the standard production medium and was compared to know whether the respective alcohols are working as a stimulator or an inhibitor, if it is a Stimulator, at which concentration it is stimulating the production rate. The production rate by Citron and its peel after exposing to the alcohols were compared with the rate of production of control.

\section{Results}

The critical parameters for citric acid production by Aspergillus niger were defined empirically, include high carbohydrate concentration but should not be more that 15 to $20 \%$. So, in order to fulfill the requirement the concentration of carbohydrates in Citron and its peel was estimated and calculated (table 1). So, $15 \mathrm{~g} / 100 \mathrm{ml}$ concentration of each Citron and its peel were calculated and were used for the present study of citric acid production.

Table 2 has shown the data regarding the production of citric acid with Aspergillus niger MTCC 281 using Citron and its wastes i.e. peel in shake flasks. The amount of sugar consumed, dry cell mass and citric acid produced was estimated (Table 2). . According to the table 2, the amount of citric acid obtained is $\mathbf{5 2 . 9 6} \mathbf{0 0 . 5 6} \mathrm{g} / \mathrm{l}$ using sucrose as a substrate, where as with Citron and its peel the yield obtained is $24.65 \pm 0.33 \mathrm{~g} / \mathrm{l}($ table 4$)$ and $\mathbf{1 0 . 8 8} \pm \mathbf{0 . 2 0} \mathrm{g} / \mathrm{l}($ table 5) respectively. The rate of yield from Citron and its peel were compared with control yield.

The effect of alcohols as stimulants at various concentrations were also tested, alcohols used were Methanol (Table 3), Ethanol (Table 4) and Butanol (Table 5). After using different concentrations of different alcohols as stimulants on all the three substrates i.e. sucrose, Citron and its peel we got $61.98 \pm 0.03 \mathrm{~g} / \mathrm{l}$ (table 3) of citric acid with sucrose as a substrate at $1.0 \%$ Methanol as a stimulant, for Citron and its peel, the amount of citric acid obtained is $29.20 \pm 0.74 \mathrm{~g} / \mathrm{l}$ and16.90 $\pm 0.25 \mathrm{~g} / \mathbf{l}$ respectively (Table 4 and 5). In all the three cases $1.0 \%$ methanol is acting as a good stimulants in compared to that of ethanol and Butanol and other concentrations of methanol. Inturn the ethanol and butanol are acting as a inhibitors and decreasing the rate of production.

Even though the amount of citric acid obtained with Citron $\mathbf{2 4 . 6 5} \pm \mathbf{0 . 3 3} \mathrm{g} / \mathrm{l}$ (table 4$)$ and its peel 10.88 $\pm \mathbf{0 . 2 0} \mathrm{g} / \mathrm{l}$ (table 5) is less than the citric acid obtained from sucrose $\mathbf{5 2 . 9 6 \pm 0 . 5 6}$ $\mathbf{g} / \mathbf{l}$ as a substrate, the amount produced from fruit and its peel are not negligible, which has enhanced after the addition of alcohol as a stimulants $29.20 \pm 0.74 \mathrm{~g} / \mathbf{l}$ and $16.90 \pm 0.25 \mathrm{~g} / \mathrm{l}$, for Citron and its peel respectively.

\section{Discussion}

Citric acid produced from Citron and its peel was compared with sucrose as a substrate for citric acid production (Table $2)$. In order to increase the yield alcohols as a stimulants were added, as expected the addition of stimulants has

\section{Volume 4 Issue 11, November 2015}




\section{International Journal of Science and Research (IJSR) \\ ISSN (Online): 2319-7064}

Index Copernicus Value (2013): 6.14 | Impact Factor (2014): 5.611

increased the yield (table 3, 4 and 5) The explanation for how the alcohols were acting as stimulants is, addition of low molecular weight alcohols to the medium increases fungal tolerance to trace metals during fermentation[14][15]. In addition, methanol markedly depressed the synthesis of cell proteins in the early stage of cultivation [16] and also increased the metabolic activity of enzyme citrate synthase. When methanol concentration was further increased, it resulted in the decreased citric acid production (Table 3, $4 \& 5)$ because of the disturbance in fungal metabolism. Methanol has also some role in conditioning the mycelia without impairing their metabolism. Similar, type of work has also been carried out by [17] [18].

\section{Conclusion}

Citric acid one of the most important bulk producing organic acid.In the present work the production of citric acid was done using Citron fruit and its waste which is considered as a muncipal waste, and was compared with the rate of production from sucrose rich media.Three different alcohols at differnet concentration were used to check the effect of alcohols on the rate of production, as a result of the same, the effect of Methonl at a concentration of $1 \%$ is proved to be acting as a stimulant. Thus, yield of citric acid can be enhanced more by considering all other parameters. By doing so we can produce one of the most important bulk producing organic acid i.e. citric acid, economically using a municipal waste, Citron peel.

Table 1: Estimation of carbohydrates in Citron and its peel

\begin{tabular}{|l|l|l|c|c|c|c|}
\hline S. No. & $\begin{array}{c}\text { Name of the } \\
\text { sample }\end{array}$ & $\begin{array}{c}\text { Vol. of } \\
\text { sample }^{l}(\mathrm{ml})\end{array}$ & $\begin{array}{c}\text { Conc.of sample for } \\
0.1 \mathrm{mg}(\mu \mathrm{g})^{2}\end{array}$ & $\begin{array}{c}\text { Conc. of sample for } \\
100 \mathrm{gm}(\mathrm{gm})\end{array}$ & $\begin{array}{c}\text { Vol. of } \\
\text { Anthrone }(\mathrm{ml})\end{array}$ & O.D. at 620 $\mathrm{nm}$ \\
\hline 1 & Citron & 1 & 5.20 & 5.20 & 4 & 0.05 \\
\hline 2 & Citron peel & 1 & 2.08 & 2.08 & 4 & 0.02 \\
\hline
\end{tabular}

1. $1 \mathrm{ml}$ of volume of the sample $=0.1 \mathrm{mg}$ of dried powder of the fruit/ sample

2. Concentration of sample was determined from the standard graph

Table 2: A.niger MTCC281 for citric acid fermentation using Citron and its peel in shake flask*

\begin{tabular}{|c|c|c|c|c|}
\hline Sl.No & Sample & Dry cell mass $(\mathrm{g} / \mathrm{l})$ & Sugar consumed $(\mathrm{g} / \mathrm{l})$ & Citric acid $(\mathrm{g} / \mathrm{l})$ \\
\hline 1 & Sucrose ( Control) & $15.97 \pm 0.49$ & $97.99 \pm 0.56$ & $52.96 \pm 0.56$ \\
\hline 2 & Citron & $9.37 \pm 0.04$ & $110.48 \pm 0.28$ & $24.65 \pm 0.33$ \\
\hline 3 & Citron peel & $10.19 \pm 0.12$ & $98.36 \pm 0.19$ & $10.88 \pm 0.20$ \\
\hline
\end{tabular}

Note:

* Fermentation period $168 \mathrm{~h}$, Sugar concentration $150 \mathrm{~g} / \mathrm{l}$, Initial pH 2.5, incubation temperature $30{ }^{0} \mathrm{C}$.

\pm Indicate standard error mean (SEM) of the mean.

Table 3: Effect of methanol, ethanol and butanol at various concentration on citric acid fermentation by the Aspergillus niger MTCC281 using Sucrose salt medium in shake flasks*

\begin{tabular}{|c|c|c|c|c|c|c|}
\hline $\begin{array}{l}\text { Sl. } \\
\text { no }\end{array}$ & Sample & Alcohol & \begin{tabular}{|c|} 
Concentration \\
$\%$
\end{tabular} & $\begin{array}{c}\text { Dry cell mass } \\
(\mathrm{g} / \mathrm{l})\end{array}$ & $\begin{array}{c}\text { Sugar consumed } \\
(\mathrm{g} / \mathrm{l})\end{array}$ & $\begin{array}{c}\text { Citric acid } \\
(\mathrm{g} / \mathrm{l})\end{array}$ \\
\hline 1 & Sucrose Control & - & - & $15.97 \pm 0.49$ & $97.99 \pm 0.56$ & $52.96 \pm 0.56$ \\
\hline \multirow{5}{*}{2} & \multirow{5}{*}{ Sucrose } & \multirow{5}{*}{ Methanol } & 0.5 & $16.02 \pm 0.42$ & $95.31 \pm 0.29$ & $56.60 \pm 1.29$ \\
\hline & & & 1.0 & $15.69 \pm 0.50$ & $96.74 \pm 0.07$ & $61.98 \pm 0.03$ \\
\hline & & & 1.5 & $15.33 \pm 0.06$ & $95.87 \pm 0.29$ & $61.66 \pm 0.38$ \\
\hline & & & 2.0 & $14.92 \pm 0.53$ & $94.92 \pm 0.38$ & $57.79 \pm 0.39$ \\
\hline & & & 2.5 & $16.43 \pm 0.73$ & $95.24 \pm 0.33$ & $53.45 \pm 0.18$ \\
\hline \multirow{5}{*}{3} & \multirow{5}{*}{ Sucrose } & \multirow{5}{*}{ Ethanol } & 0.5 & $16.51 \pm 0.37$ & $100.40 \pm 0.35$ & $49.60 \pm 1.29$ \\
\hline & & & 1.0 & $16.93 \pm 0.26$ & $101.44 \pm 0.74$ & $53.98 \pm 0.03$ \\
\hline & & & 1.5 & $16.96 \pm 0.03$ & $101.92 \pm 0.88$ & $53.66 \pm 0.38$ \\
\hline & & & 2.0 & $16.48 \pm 0.51$ & $102.70 \pm 1.31$ & $50.79 \pm 0.39$ \\
\hline & & & 2.5 & $16.75 \pm 0.38$ & $101.26 \pm 0.59$ & $46.45 \pm 0.18$ \\
\hline \multirow{5}{*}{4} & \multirow{5}{*}{ Sucrose } & \multirow{5}{*}{ Butanol } & 0.5 & $13.98 \pm 0.39$ & $101.29 \pm 0.25$ & $38.93 \pm 0.57$ \\
\hline & & & 1.0 & $13.68 \pm 0.49$ & $102.76 \pm 0.06$ & $42.31 \pm 0.87$ \\
\hline & & & 1.5 & $13.35 \pm 0.06$ & $101.86 \pm 0.28$ & $39.66 \pm 0.38$ \\
\hline & & & 2.0 & $12.90 \pm 0.50$ & $100.93 \pm 0.38$ & $36.46 \pm 0.28$ \\
\hline & & & 2.5 & $14.42 \pm 0.70$ & $101.26 \pm 0.33$ & $32.79 \pm 0.31$ \\
\hline
\end{tabular}

* Initial sugar concentration $150 \mathrm{~g} / \mathrm{l}$, Fermentation period of $168 \mathrm{~h}$, incubation, $30{ }^{\circ} \mathrm{C}$, and initial pH 2.5 .

Each value is an average of three parallel replicates. \pm Indicates standard error mean among the replicates. 


\section{International Journal of Science and Research (IJSR) \\ ISSN (Online): 2319-7064 \\ Index Copernicus Value (2013): 6.14 | Impact Factor (2014): 5.611}

Table 4: Effect of Methanol, Ethanol \& Butanol at various concentration on citric acid fermentation by the Aspergillus niger 281 using Citron as a substrate in shake flasks*

\begin{tabular}{|c|c|c|c|c|c|c|}
\hline $\begin{array}{l}\text { Sl. } \\
\text { no }\end{array}$ & Sample & Alcohol & $\begin{array}{c}\text { Concentration } \\
\% \\
\end{array}$ & $\begin{array}{c}\text { Dry cell mass } \\
(\mathrm{g} / \mathrm{l})\end{array}$ & $\begin{array}{c}\text { Sugar consumed } \\
(\mathrm{g} / \mathrm{l})\end{array}$ & $\begin{array}{c}\text { Citric acid } \\
(\mathrm{g} / \mathrm{l})\end{array}$ \\
\hline 1 & Citron- Control & - & - & $9.37 \pm 0.04$ & $110.48 \pm 0.28$ & $24.65 \pm 0.33$ \\
\hline \multirow{5}{*}{2} & \multirow{5}{*}{ Citron } & \multirow{5}{*}{ Methanol } & 0.5 & $8.22 \pm 0.59$ & $108.85 \pm 0.12$ & $26.65 \pm 0.61$ \\
\hline & & & 1.0 & $8.40 \pm 0.73$ & $109.38 \pm 0.71$ & $29.20 \pm 0.74$ \\
\hline & & & 1.5 & $7.94 \pm 0.50$ & $108.89 \pm 0.26$ & $27.42 \pm 0.53$ \\
\hline & & & 2.0 & $8.96 \pm 0.36$ & $109.92 \pm 0.75$ & $24.63 \pm 0.34$ \\
\hline & & & 2.5 & $8.20 \pm 0.36$ & $109.53 \pm 0.28$ & $24.18 \pm 0.13$ \\
\hline \multirow{5}{*}{3} & \multirow{5}{*}{ Citron } & \multirow{5}{*}{ Ethanol } & 0.5 & $10.00 \pm 0.37$ & $114.97 \pm 0.05$ & $21.04 \pm 0.17$ \\
\hline & & & 1.0 & $10.27 \pm 0.43$ & $115.47 \pm 0.68$ & $23.71 \pm 0.32$ \\
\hline & & & 1.5 & $9.81 \pm 0.22$ & $115.10 \pm 0.26$ & $22.87 \pm 0.34$ \\
\hline & & & 2.0 & $11.04 \pm 0.30$ & $116.04 \pm 0.79$ & $19.88 \pm 0.25$ \\
\hline & & & 2.5 & $10.05 \pm 0.08$ & $115.74 \pm 0.21$ & $18.65 \pm 0.54$ \\
\hline \multirow{5}{*}{4} & \multirow{5}{*}{ Citron } & \multirow{5}{*}{ Butanol } & 0.5 & $5.35 \pm 0.63$ & $112.82 \pm 0.36$ & $15.21 \pm 0.54$ \\
\hline & & & 1.0 & $5.39 \pm 0.44$ & $113.65 \pm 0.68$ & $19.46 \pm 0.86$ \\
\hline & & & 1.5 & $4.93 \pm 0.17$ & $113.15 \pm 0.27$ & $16.38 \pm 0.26$ \\
\hline & & & 2.0 & $5.89 \pm 0.55$ & $113.89 \pm 0.58$ & $12.30 \pm 0.32$ \\
\hline & & & 2.5 & $5.13 \pm 0.17$ & $113.82 \pm 0.29$ & $8.08 \pm 0.32$ \\
\hline
\end{tabular}

Note:

* Initial sugar concentration $150 \mathrm{~g} / \mathrm{l}$, Fermentation period of $168 \mathrm{~h}$, incubation, $30^{\circ} \mathrm{C}$, initial $\mathrm{pH} 2.5$.

Each value is an average of three parallel replicates. \pm Indicates standard error mean among the replicates

Table 5: Effect of Methanol, Ethanol \& Butanol at various concentration on citric acid fermentation by the Aspergillus niger 281 using Citron peel as a substrate in shake flasks*

\begin{tabular}{|c|c|c|c|c|c|c|}
\hline $\begin{array}{l}\text { Sl. } \\
\text { no }\end{array}$ & Sample & Alcohol & $\begin{array}{c}\text { Concentration } \\
\%\end{array}$ & $\begin{array}{l}\text { Dry cell mass } \\
(\mathrm{g} / \mathrm{l})\end{array}$ & $\begin{array}{c}\text { Sugar consumed } \\
(\mathrm{g} / \mathrm{l})\end{array}$ & $\begin{array}{l}\text { Citric acid } \\
(\mathrm{g} / \mathrm{l})\end{array}$ \\
\hline 1 & Citron peel- Control & - & - & $10.19 \pm 0.12$ & $98.36 \pm 0.19$ & $10.88 \pm 0.20$ \\
\hline \multirow{5}{*}{2} & \multirow{5}{*}{ Citron Peel } & \multirow{5}{*}{ Methanol } & 0.5 & $8.25 \pm 0.27$ & $93.92 \pm 0.41$ & $14.02 \pm 0.28$ \\
\hline & & & 1.0 & $8.20 \pm 0.21$ & $94.42 \pm 0.30$ & $16.90 \pm 0.25$ \\
\hline & & & 1.5 & $7.70 \pm 0.57$ & $94.25 \pm 0.59$ & $15.78 \pm 0.27$ \\
\hline & & & 2.0 & $8.32 \pm 0.14$ & $94.62 \pm 0.75$ & $9.67 \pm 0.62$ \\
\hline & & & 2.5 & $8.24 \pm 0.48$ & $94.89 \pm 0.45$ & $6.88 \pm 0.44$ \\
\hline \multirow{5}{*}{3} & \multirow{5}{*}{ Citron Peel } & \multirow{5}{*}{ Ethanol } & 0.5 & $10.90 \pm 0.20$ & $105.21 \pm 0.38$ & 0.00 \\
\hline & & & 1.0 & $10.84 \pm 0.54$ & $105.34 \pm 0.65$ & 0.00 \\
\hline & & & 1.5 & $10.71 \pm 0.45$ & $105.20 \pm 0.40$ & 0.00 \\
\hline & & & 2.0 & $10.94 \pm 0.30$ & $105.94 \pm 0.79$ & 0.00 \\
\hline & & & 2.5 & $9.95 \pm 0.08$ & $105.97 \pm 0.51$ & 0.00 \\
\hline \multirow{5}{*}{4} & \multirow{5}{*}{ Citron Peel } & \multirow{5}{*}{ Butanol } & 0.5 & $6.51 \pm 0.56$ & $102.98 \pm 0.45$ & 0.00 \\
\hline & & & 1.0 & $6.23 \pm 0.73$ & $103.48 \pm 0.82$ & 0.00 \\
\hline & & & 1.5 & $6.13 \pm 0.40$ & $102.98 \pm 0.50$ & 0.00 \\
\hline & & & 2.0 & $6.75 \pm 0.36$ & $103.72 \pm 0.74$ & 0.00 \\
\hline & & & 2.5 & $6.30 \pm 0.49$ & $103.99 \pm 0.48$ & 0.00 \\
\hline
\end{tabular}

Note:

* Initial sugar concentration $150 \mathrm{~g} / \mathrm{l}$, Fermentation period of $168 \mathrm{~h}$, incubation, $30^{\circ} \mathrm{C}$, initial $\mathrm{pH} 2.5$.

Each value is an average of three parallel replicates. \pm Indicates standard error mean among the replicates.

\section{References}

[1] Torres, N.V., Alvarez-Vasquez, F. \& Voit, E.O. Optimization of biotechnological processes with Ssystem models. Handbook of fungal Biotechnology, $2^{\text {nd }}$ Edition, Marcel Dekker, Inc. New York, p. (2002) 114.

[2] Ranya, A.A., Osama, M.S. \& Mustafa, A.B. Production and purification of citric acid by A.niger. Alex. J. Pharm, Sci., 13(1), (1999)57-60.

[3] Karaklins, R., Lemba, J. \& Ciesturs, U. Biotechnology for organic acid production. J. Biotechnol. 5(6) (2001) 281-283.
[4] Vanags, J. \& Viesturs, U. Local mixing intensity measurements for the food industry and biotechnology. Food Technol. \& Biotechnol., 39(1), (2001) 59-65.

[5] Johnson, S. Do Mitochondria regulate cellular iron homeostasis through citric acid and haem production? Implication for cancer and other diseases. Med. Hypoth., 60(1), (2003) 106-111.

[6] Ali, S., Haq, I. \& Iqbal, J. Exploitation of raw sugar cane molasses for citric acid production by Aspergillus niger. Online J. Biol. Scis., 32(3), (2002) 31-35.

[7] Kubicek, C.P. The role of the citric acid cycle in fungal organic acid fermentations. Biochemical Sym., 54, (1988) 113-126.

[8] Morris, D. L. Quantitative determination of carbohydrate with Dreywood's anthrone reagent. Science,(1948) 107:254

[9] Morse, Anthrone in Estimating Low Concentrations of Sucrose. Anal. Chem. 19 (12),(1947) pp 1012-1013. DOI: $10.1021 / \mathrm{ac} 60012 \mathrm{a} 021$ 


\section{International Journal of Science and Research (IJSR) \\ ISSN (Online): 2319-7064}

Index Copernicus Value (2013): 6.14 | Impact Factor (2014): 5.611

[10] Roukas, T. Citric acid production from carob pod by solid-state fermentation. Enzym. Microb. Technol. 24, (1999) 54-59.

[11] Roukas, T. Carob pod, a new substrate for citric acid production by Aspergillus niger. App. Biochem. \& Biotechnol., 74(1), (1998) 43-54.

[12]R.D. Williams, L. Wicks, H.R.Bierman, and W.H.Olmsted, Carbohydrate Values of Fruits and Vegetables., J.Nutr., 19,(1940) 593-604

[13] Kristiansen, B., Mattey, M. \& Linden, J. Citric acid Biotechnology. Taylor and Francis Inc. Philadelphia. Pp. (1999) 55-62.

[14]Zakowska, Z. \& Joloka, A. Toxic components of molasses. Acta Biotechnol., 4, (1984) 171-178.

[15] Moyer, A.J. Effect of alcohols on the mycological production of citric acid in surface and submerged culture. Appl. Microbial., 1, (1953) 1-7.

[16] Sanjay, K. and Sharma, P. A highly performance fermentation process for production of citric acid from sugarcane molasses. Journal of Microbiology, vol. 23, (1994) p. 211-217.

[17]Hang, Y.D. \& Woodams, E.E. Solid- state fermentation of apple pomace for citric acid production. J. Appl. Microbiol. \& Biotechnol., 2(2), (1986)283-287.

[18] Navaratnam, P., Arasaratnm, V. \& Balasubramaniam, K. Channelling of glucose by methanol from citric acid production from Aspergillus niger. Worl J. Microbiol. \& Biotechnol., 14(4), (1998) 559-563. 